\title{
FEATURE \\ Making conservation count: The importance of assessing resources and documenting outcomes to USDA
}

Bill Northey

0 ne of the requests of the 2018 Farm Bill was to refocus USDA's efforts to document outcomes of conservation programs on private lands. We agree. It's imperative that we show that USDA conservation programs work and that farmers and ranchers using voluntary conservation efforts are making a difference. In fact, USDA has a long history of working toward this goal.

For the past 17 years, USDA has been developing the science baseline and methods to carry out assessments and document conservation outcomes with the establishment of its Conservation Effects Assessment Project (CEAP). In 2003, the USDA's Natural Resources Conservation Service partnered with USDA's Agricultural Research Service (ARS), National Institute of Food and Agriculture (NIFA), National Agricultural Statistics Service, and Farm Service Agency, as well as universities and other partners, to develop the science basis for managing a productive agricultural landscape for environmental quality and quantifying the environmental effects of conservation practices and programs (Mausbauch and Dedrich 2004). ARS played a key role in developing the science and innovation needed for these studies.

Partnerships through CEAP are building capacity and leveraging the resources needed to carry out these cutting-edge scientific assessments of environmental effects, and the cooperation of producers is key to helping USDA make conservation count. Voluntary conservation adoption and stewardship behaviors of landowners and producers are needed to continue making progress toward both local and regional water quality goals as part of the solution.

CEAP Watershed Assessment Studies focus on measuring the effects of conservation on water and soil resources in small watersheds and at various scales within

Bill Northey is USDA Under Secretary for Farm Production and Conservation, Washington, DC. watersheds (e.g., edge-of-field monitoring, figure 1). This issue of the Journal of Soil and Water Conservation summarizes the findings of the first 15 years of CEAP Watershed Assessment Studies and presents measured and modeled effects of conservation practices in 120 research studies of water quality concerns in ARS Benchmark and NIFA-CEAP watersheds. In addition to documenting successes, these studies provide insights for increasing effectiveness of future conservation efforts to improve water quality and watershed protection and restoration.

Most importantly, these studies show that conservation works. Thirteen of 21 ARS Benchmark CEAP watersheds demonstrated measurable water quality improvements at subwatershed or watershed scales for at least one item monitored (Moriasi et al. 2020). In addition, some earlier published studies found that in 6 of 13 NIFA-CEAP watersheds, the water quality improvements could be attributed to conservation practices (Osmond et al. 2012). That means that, despite the difficulty of isolating the impacts of conservation practices from the wide range of factors affecting water quality, over $55 \%$ of these long-term watersheds have measured water quality benefits from conservation at the small watershed scale.

Although these studies and others have shown conservation successes, more work remains to be done.

The many expectations in the recent farm bill for conservation programs in watersheds include assessing water quality, water scarcity, and other resource concerns. These studies need to be conducted over the long-term and produce credible data rooted in science, yet expectations dictate they also need to provide timely results to be applied to adaptive management of agricultural systems. Ultimately, the knowledge we gain through these studies should be used to build a more resilient agricultural system, and to inform watershed and conservation planning at local levels and program design and delivery approaches at larger scales.

\section{Figure 1}

Conservation Effects Assessment Project edge-of-field network site in Ohio. Photo by USDA ARS Soil Drainage Research Unit, Columbus, Ohio.

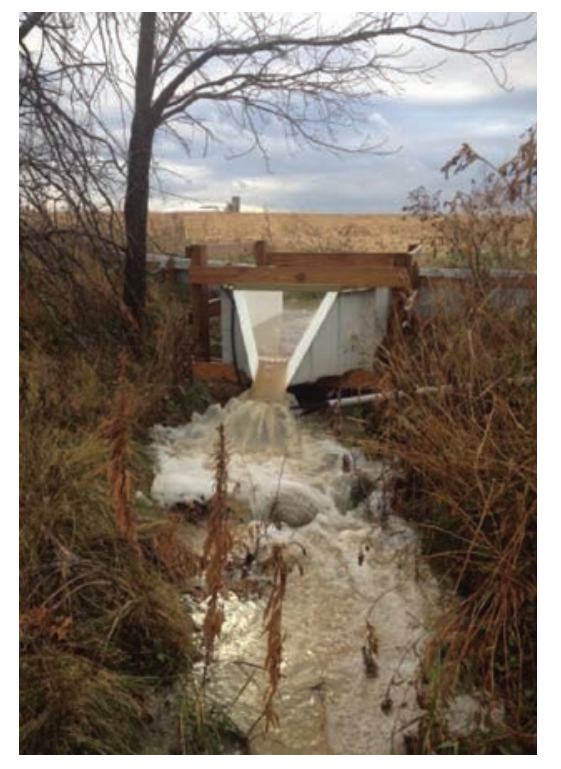

We are grateful to our USDA team members who support CEAP. Their work helps us better shape our programs for the future to benefit both farmers and ranchers as well as our natural resources. We hope you enjoy this special issue!

\section{REFERENCES}

Mausbach, M.J., and A.R. Dedrick. 2004. The length we go-measuring environmental benefits of conservation practices. Journal of Soil and Water Conservation 59(5):96A-103A.

Moriasi, D.N., L.F. Duriancik, J. Sadler, T. Tsegaye, J.L. Steiner, M.A. Locke, T.C. Strickland, and D.L. Osmond. 2020. Quantifying the impacts of CEAP watershed assessments: The first fifteen years. Journal of Soil and Water Conservation 75(3):57A-74A, doi:10.2489/jswc.75.3.57A.

Osmond, D., D. Meals, D. Hoag, M. Arabi, A. Luloff, G. Jennings, M. McFarland, J. Spooner, A. Sharpley, and D. Line. 2012. Improving conservation practices programming to protect water quality in agricultural watersheds: Lessons learned from the National Institute of Food and Agriculture-Conservation Effects Assessment Project. Journal of Soil and Water Conservation 67(5):122A-127A, doi:10.2489/jswc.67.5.122A. 